\title{
Antibiosis Components and Antioxidant Defense of Rice as Mechanism of Resistance to Brown Planthopper, Nilaparvata lugens (Stål)
}

\author{
I. SINGH, P.S. SARAO* and N. SHARMA \\ Rice Section, Department of Plant Breeding and Genetics \\ Punjab Agricultural University, Ludhiana, Punjab, India-141 004
}

(Received 2 May 2016; Accepted 20 September 2016)

\begin{abstract}
The role of antibiosis components and antioxidant defense of rice genotypes, namely CR3006-8-2, RP4918-221, KAUM182-1, T12, IHRT-ME-25, W1263, Ptb33 (resistant check) and TN1 (susceptible check) was studied by phenotyping them against brown planthopper (BPH). Three genotypes, namely KAUM182-1, RP4918-221 and CR3006-8-2 were resistant to BPH and significantly low damage score (1.97-3.00); honeydew excretion area (46.76-49.64 $\left.\mathrm{mm}^{2}\right)$; nymphal survival $(60.60-66.40 \%)$ and growth index $(2.98-3.86)$ was recorded on them. Higher constitutive and induced level of soluble phenolics, peroxidase and polyphenol oxidase was observed in resistant genotypes without and with BPH infestation. A negative relationship between honeydew excretion, nymphal emergence, growth index and nymphal survival was observed with these biochemical constituents. Likewise, a reverse trend was observed between nymphal development period and biochemical constituents. These genotypes have emerged as a new source of resistance to BPH which can be used in hybridization programme to breed durable $\mathrm{BPH}$ resistant rice varieties.
\end{abstract}

Keywords: rice, brown planthopper, antibiosis, biochemical, antioxidant, resistance

\section{Introduction}

Rice, Oryza sativa L. (Poaceae), is cultivated extensively in the most diverse ecosystems of tropical and sub-tropical regions of the world. Among various biotic constraint of rice production, the insect pests are of prime importance and warm humid environment of the crop is also conducive for their survival and proliferation (Heong and Hardy 2009). The brown planthopper, Nilaparvata lugens (Stål) (Homoptera: Delphacidae) (BPH) is one of the most damaging insect pests of rice and a typical phloem sap feeder. Being an r-strategist pest BPH increases exponentially and causes huge yield losses due to excessive removal of plant sap, the condition known as, 'hopper burn'. Susceptible cultivars suffer 40 to 70 per cent yield loss in case of serious pest infestation (Heong and Hardy 2009). BPH also transmits virus diseases like grassy stunt, ragged stunt and wilted stunt.

\footnotetext{
*Corresponding author; E-mail: preetento@gmail.com
} 
By regular monitoring of rice field, farmers can manage this pest effectively by need based application of recommended insecticides (Sarao 2015). However, application of un-recommended insecticides for the control of this insect disrupts the ecological balance and cause pest resurgence and development of multiple insecticide resistance (Matsumura and Morimura 2010). Hence, cultivation of resistant varieties is an environmentally sound strategy for population management of this insect (Horgan et al. 2015; Sarao et al. 2016). The natural enemy population will also increase on the resistant varieties due to less pesticide applications (Gurr 2011). Host plant show very diverse kind of reactions upon wounding and feeding by insect pests and nutritional biochemistry of a plant will also alter in this response (Vanitha et al. 2011). Inducible resistance to insect pests is an important tool for the scientists to develop a variety resistant to insect pests (Jena and Kim 2010). But the role of antibiosis mechanisms, enzymatic and non-enzymatic antioxidants involved in plant defense against BPH feeding has been understood to a limited extent. There are suites of defense related enzymes in plants, however, peroxidases (PO), polyphenol oxidases (PPO) are key enzymes involved in oxidation of phenols and inhibit protein digestion. Catalase (CAT) and peroxidases rapidly destroy $\mathrm{H}_{2} \mathrm{O}_{2}$, but they allow low steady-state levels to persist to maintain signalling pathways (Noctor and Foyer 1998; Qiu 2011). Hence, the present studies were undertaken to quantify the antibiosis level and activity of soluble phenolics, CAT, PO and PPO molecules in selected genotypes so as to use resistant genotypes to breed BPH resistant variety which will form an integral part of integrated pest management.

\section{Materials and Methods}

\section{Plant and insect material}

Eight rice genotypes, viz. CR3006-8-2, RP4918-221, KAUM182-1, T12, IHRT-ME-25, W1263, Ptb33 and TN1 were obtained from Indian Institute of Rice Research, India. BPH was reared on 30-day-old TN1 plants under glasshouse conditions of Department of Plant Breeding and Genetics, Punjab Agricultural University, India positioned at $30^{\circ} 54^{\prime} \mathrm{N}$ and $75^{\circ} 48^{\prime} \mathrm{E}$ as per the protocol developed by Heinrichs et al. (1985) at temperature of $28 \pm 2{ }^{\circ} \mathrm{C}, 75 \pm 5 \%$ relative humidity and $14: 10 \mathrm{~h}$ light : dark photoperiod.

\section{Phenotyping}

\section{Seed box screening}

The seeds $(15-20)$ of test genotypes were sown in seed box $(0.45 \times 0.35 \times 0.10 \mathrm{~m})$ containing well-puddled soil in rows of $3.5 \mathrm{~cm}$ apart as per standard protocol (Heinrichs et al. 1985). Each genotype was replicated thrice in complete randomized block design in the tray. Ten-day-old seedlings were infested with $2^{\text {nd }}-3^{\text {rd }}$ instar stage nymphs at a rate of 6-8 insects per seedling (Heinrichs et al. 1985). Ptb33 and TN1 were used as standard resist- 
ant and susceptible checks, respectively. Damage score on each seedling was recorded on a 0-9 scale when 90-100\% plants of TN1 were dead following Standard Evaluation System of IRRI (2014). A score of 0 represents no visible damage, whereas a score of 9 represents complete drying of plant. Each genotype with a mean rating of 0-3.49, 3.50-5.49 and 5.50-9.00 was designated as resistant, moderately resistant and susceptible, respectively (Heinrichs et al. 1985).

\section{Honeydew excretion}

Feeding rate of $\mathrm{BPH}$ female adult on each genotype was assessed according to Heinrichs et al. (1985). Five one-day-old BPH females starved for $2 \mathrm{~h}$ before release were allowed to feed for $24 \mathrm{~h}$ at the leaf sheath portion of 30-day-old seedlings in glass chimneys. There were five replications for each genotype. Circular pieces of Whatman filter paper no. 1 were dipped in the dye solution of $0.1 \%$ bromocresol green in ethyl alcohol. These coloured papers were placed on a plastic plate and the plant was covered with glass chimney. The insect honeydew stains were appeared as blue colour spots on contact with filter paper. The filter paper was removed after $24 \mathrm{~h}$ and spot area was measured on graph paper.

\section{Nymphal emergence}

Two pairs of newly emerged insects were released on 30-day-old plants of each genotype kept in the glass chimneys. There were five replications for each genotype. The daily emerged nymphs were counted till the day they were stopped emerging (Khan and Saxena 1985).

\section{Nymphal survival and development period}

Twenty newly emerged nymphs from nymphal emergence experiment were released on 30-day-old plants of each test genotypes covered with glass chimneys. There were five replications for each genotype. For nymphal development period, ecdysis was observed on daily basis. The observations were recorded for different instars till the BPH reached the adult stage.

\section{Growth index}

Growth index of each tested genotype was computed by dividing the data obtained from the experiment on nymphal survival with that from nymphal development period (Alagar and Suresh 2007). 


\section{Biochemical constituents}

\section{Soluble phenolics}

It was estimated as per the method given by Swain and Hills (1959). The leaves of 30day-old rice test genotypes were collected and dried in incubator at $55-65^{\circ} \mathrm{C}$. The dried leaf samples $(40 \mathrm{mg}$ ) were refluxed with $5 \mathrm{ml}$ of $80 \%$ aqueous methanol for $1 \mathrm{~h}$ at 70 $75{ }^{\circ} \mathrm{C}$. The refluxed content was filtered and final volume was made to $10 \mathrm{ml}$ by adding $80 \%$ of methanol. It was estimated by using Folin phenol and saturated $\mathrm{Na}_{2} \mathrm{CO}_{3}$. Absorbance was recorded at $760 \mathrm{~nm}$ against blank. Concentration of soluble phenolics was determined from standard curve made by using gallic acid with a range of 10-50 $\mu \mathrm{g}$.

\section{Catalase (CAT)}

It was estimated as per the method given by Chance and Maehly (1955). Catalase was extracted from leaves of 30 -day-old rice genotypes with $0.05 \mathrm{M}$ sodium phosphate buffer ( $\mathrm{pH} 7.5$ ) having $1 \%$ polyvinyl pyrolidone. The catalase activity was determined by using $0.05 \mathrm{M}$ sodium phosphate buffer, $0.05 \mathrm{ml}$ of enzyme extract and $1 \mathrm{ml} \mathrm{of} \mathrm{H}_{2} \mathrm{O}_{2}$. The decrease in absorbance was measured at $240 \mathrm{~nm}$. The mixture without $\mathrm{H}_{2} \mathrm{O}_{2}$ was used as blank.

\section{Peroxidase (PO)}

It was determined as per method given by Shannon et al. (1966). Peroxidase was extracted from leaves of 30-day-old rice genotypes with $2 \mathrm{ml}$ of $0.1 \mathrm{M}$ potassium phosphate buffer (pH 7.5), 1\% PVP along with $1 \mathrm{mM}$ EDTA and $10 \mathrm{mM} \beta$-mercaptoethanol. The enzyme activity was determined by appearance of brown colour from guaiacol to tetraguaiacol in presence of $\mathrm{H}_{2} \mathrm{O}_{2}$. Reagent used was $0.05 \mathrm{M}$ guaiacol in $0.1 \mathrm{M}$ potassium phosphate buffer ( $\mathrm{pH}$ 6.5). The reaction was started by adding $0.1 \mathrm{ml}$ of $0.8 \mathrm{M} \mathrm{H}_{2} \mathrm{O}_{2}$ and the change in absorbance was recorded at wavelength of $470 \mathrm{~nm}$ of spectrophotometer continuously for $3 \mathrm{~min}$ at interval of $30 \mathrm{~s}$. The reaction mixture without $\mathrm{H}_{2} \mathrm{O}_{2}$ was used as blank.

\section{Polyphenol oxidase (PPO)}

It was estimated as per the method given by Bastin and Unluer (1972). Polyphenol oxidase was extracted from leaves of 30-day-old rice genotypes with $5 \mathrm{ml}$ of ice cold $0.1 \mathrm{M}$ tris HCL buffer ( $\mathrm{pH} 7.5$ ) having $5 \mathrm{mM} \beta$-mercaptoethanol. The reagent used was $0.01 \mathrm{M}$ catechol in $0.1 \mathrm{M}$ phosphate buffer ( $\mathrm{pH}$ 6.0). For analysis, $2.5 \mathrm{ml}$ of $0.01 \mathrm{M}$ catechol was taken and $0.2 \mathrm{ml}$ of enzyme extract was added in it. The increase in absorbance was recorded at $495 \mathrm{~nm}$ for $3 \mathrm{~min}$. at interval of every $30 \mathrm{~s}$. 


\section{Data analysis}

The data obtained from various experiments related to antibiosis parameters and biochemical factors were analysed in a CRD design using ANOVA with the help of SAS 9.2 software. The different treatment means were separated by least significant difference test (LSD) at $p=0.05$ (Gomez and Gomez 1984). Pearson's correlation coefficient was used as a measure of the relationship between different study parameters.

\section{Results}

\section{Antibiosis studies}

The damage score differed significantly among different selected genotypes (1.58 to 9.00) (Table 1). Significantly least damage score was recorded on KAUM182-1, CR3006-8-2 and RP4918-221. Similarly, IHRT-ME-25, W1263 and T12 fall under moderate resistant

Table 1. Seed box screening, honeydew excretion and nymphal emergence of $N$. lugens on selected rice genotypes

\begin{tabular}{|c|c|c|c|c|}
\hline Genotype & Designation/Gene & $\begin{array}{c}\text { Seed box score } \\
(\text { Mean } \pm \text { SE })\end{array}$ & $\begin{array}{c}\text { Honeydew excretion } \\
\left(\mathrm{mm}^{2}\right) \\
(\text { Mean } \pm \text { SE })\end{array}$ & $\begin{array}{l}\text { Nymphal emergence } \\
\quad(\text { Mean } \pm \text { SE) }\end{array}$ \\
\hline RP4918-221 & $\begin{array}{c}\text { Swarna } \times O \text {. nivara } \\
(\mathrm{U})\end{array}$ & $3.00 \pm 0.33^{\mathrm{c}}$ & $49.64 \pm 0.47^{c}$ & $\begin{array}{c}78.20 \pm 0.35^{\mathrm{ef}} \\
(8.83)\end{array}$ \\
\hline KAUM182-1 & $\begin{array}{c}\text { Gouri } \times \\
\text { Thavalakannan }(\mathrm{U})\end{array}$ & $1.97 \pm 0.34^{\mathrm{cd}}$ & $46.76 \pm 0.17^{\mathrm{cd}}$ & $\begin{array}{c}69.20 \pm 0.06^{\mathrm{fg}} \\
(8.31)\end{array}$ \\
\hline $\mathrm{T} 12$ & Acc.56989 (bph7) & $5.39 \pm 0.25^{b}$ & $84.52 \pm 0.37^{b}$ & $\begin{array}{c}117.60 \pm 0.50^{\mathrm{b}} \\
(10.83)\end{array}$ \\
\hline IHRT-ME-25 & JKRH2064 (U) & $5.46 \pm 0.43^{b}$ & $79.48 \pm 0.22^{b}$ & $\begin{array}{c}101.40 \pm 0.56^{\mathrm{cd}} \\
(10.04)\end{array}$ \\
\hline W1263 & $\begin{array}{l}\text { Eswarakorra× } \\
\text { MTU15 (U) }\end{array}$ & $5.44 \pm 0.040^{\mathrm{b}}$ & $51.76 \pm 0.34^{\mathrm{c}}$ & $\begin{array}{c}110.60 \pm 0.32^{\mathrm{bc}} \\
(10.51)\end{array}$ \\
\hline CR3006-8-2 & $\begin{array}{c}\text { Pusa } 44 \times \text { Salkathi } \\
(\mathrm{U})\end{array}$ & $2.86 \pm 0.40^{\mathrm{cd}}$ & $48.56 \pm 0.47^{c}$ & $\begin{array}{c}88.00 \pm 0.46^{\mathrm{de}} \\
(9.36)\end{array}$ \\
\hline Ptb33 & $\begin{array}{c}\text { Arikkirai } \\
(b p h 2+B p h 3)\end{array}$ & $1.58 \pm 0.09^{\mathrm{d}}$ & $35.08 \pm 0.36^{\mathrm{d}}$ & $\begin{array}{c}62.40 \pm 0.22^{\mathrm{g}} \\
(7.88)\end{array}$ \\
\hline TN1 & None & $9.00 \pm 0.00^{\mathrm{a}}$ & $190.40 \pm 0.26^{\mathrm{a}}$ & $\begin{array}{c}230.80 \pm 0.44^{\mathrm{a}} \\
(15.17)\end{array}$ \\
\hline Df & & 7 & 7 & 7 \\
\hline Error df & & 16 & 32 & 32 \\
\hline$F$-value & & 62.85 & 99.82 & 22.84 \\
\hline$p$-value & & $<0.0001$ & $<0.0001$ & $<0.0001$ \\
\hline $\mathrm{CD}(p=0.05)$ & & 1.32 & 8.06 & $(0.75)$ \\
\hline
\end{tabular}

$\mathrm{U}=$ unknown; Figures in parentheses are the means of $\bigvee_{\mathrm{n}}+1$ transformations; Means with the same letter within a column are not significantly different (LSD: $P>0.05$ ). 


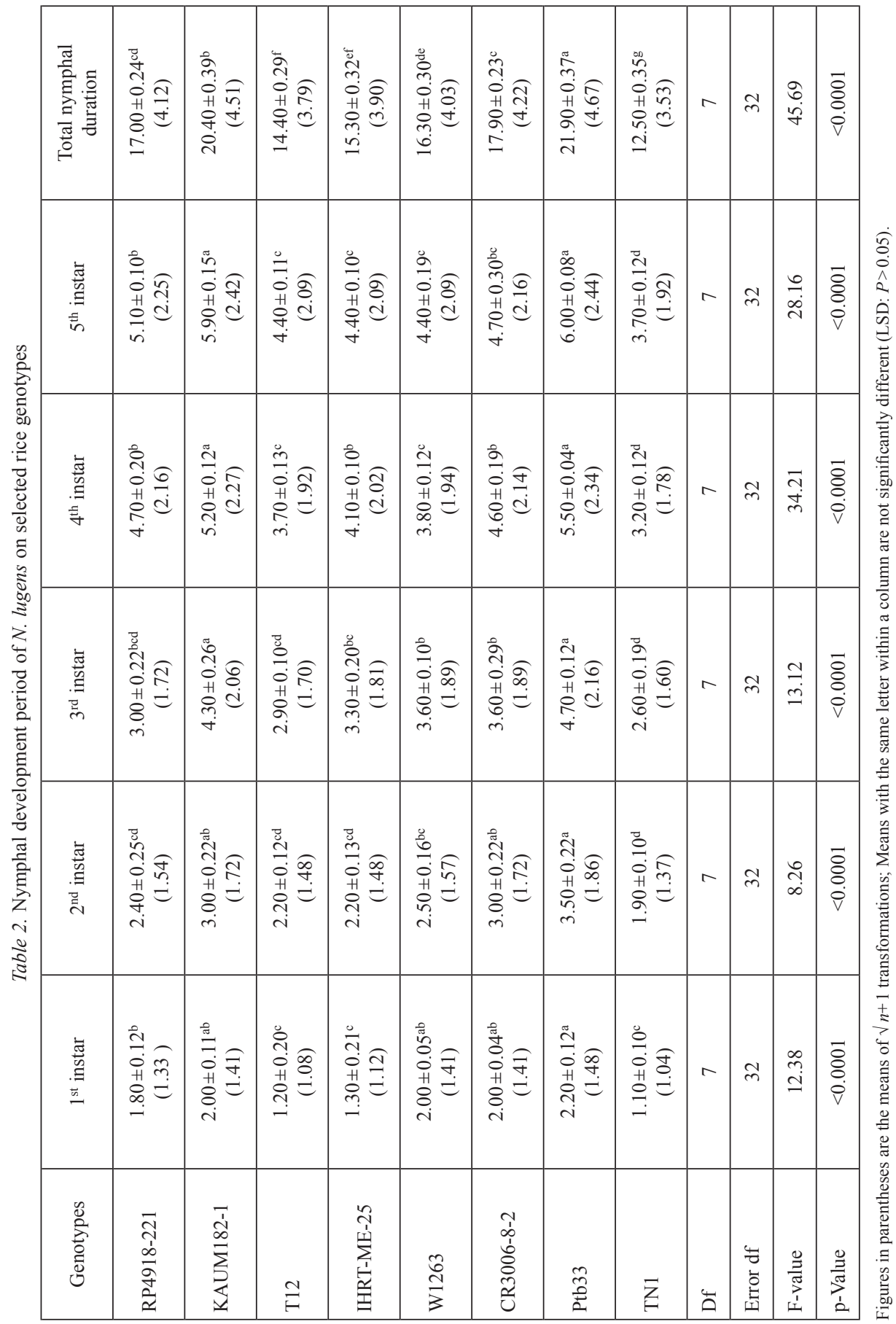

Cereal Research Communications 45, 2017 
category. The area of honeydew excretion varied significantly among genotypes (35.08$190.40 \mathrm{~mm}^{2}$ ) and it was in the ascending order among genotypes as Ptb33, KAUM182-1, CR3006-8-2, RP4918-221, W1263, IHRT-ME-25, T12 and TN1 (Table 1).

The total nymphal emergence was significantly low in resistant genotypes than in other genotypes (Table 1). The nymphal development period of all the five instars of BPH varied significantly (Table 2). The nymphal duration was prolonged on resistant genotypes than on moderately resistant genotypes (Table 2). Nymphal survival differed significantly among different selected genotypes and average survival ranged from 49.4098.79\%. Significantly least nymphal survival was observed on Ptb33 followed by KAUM182-1, RP4918-221 and CR3006-8-2 (Table 3). Likewise, significantly least growth index was observed on Ptb33 and KAUM182-1 followed by CR3006-8-2 and RP4918-221 whereas, the index was highest on TN1 (Table 3).

Table 3. Nymphal survival and growth index of $N$. lugens on selected rice genotypes

\begin{tabular}{|c|c|c|}
\hline Genotype & $\begin{array}{l}\text { Nymphal survival (\%) } \\
(\text { Mean } \pm \text { SE) }\end{array}$ & $\begin{array}{c}\text { Growth index } \\
(\text { Mean } \pm \text { SE) }\end{array}$ \\
\hline RP4918-221 & $\begin{array}{c}65.20 \pm 0.31^{\mathrm{c}} \\
(53.83)\end{array}$ & $3.86 \pm 0.84^{\mathrm{de}}$ \\
\hline KAUM182-1 & $\begin{array}{c}60.60 \pm 0.34^{\mathrm{d}} \\
(51.10)\end{array}$ & $2.98 \pm 0.11^{\mathrm{ef}}$ \\
\hline $\mathrm{T} 12$ & $\begin{array}{c}74.20 \pm 0.30^{\mathrm{b}} \\
(59.57)\end{array}$ & $5.16 \pm 0.25^{b}$ \\
\hline IHRT-ME-25 & $\begin{array}{c}73.80 \pm 0.28^{b} \\
(59.27)\end{array}$ & $4.85 \pm 0.27^{b c}$ \\
\hline W1263 & $\begin{array}{c}74.80 \pm 0.25^{b} \\
(59.94)\end{array}$ & $4.59 \pm 0.19^{b c}$ \\
\hline CR3006-8-2 & $\begin{array}{c}66.40 \pm 0.38^{c} \\
(54.32)\end{array}$ & $3.04 \pm 0.52^{\mathrm{de}}$ \\
\hline Ptb33 & $\begin{array}{c}49.40 \pm 0.13^{\mathrm{e}} \\
(44.63)\end{array}$ & $2.26 \pm 0.10^{\mathrm{df}}$ \\
\hline TN1 & $\begin{array}{c}98.79 \pm 0.38^{\mathrm{a}} \\
(84.21)\end{array}$ & $7.93 \pm 0.23^{\mathrm{a}}$ \\
\hline Df & 7 & 7 \\
\hline Error df & 32 & 32 \\
\hline$F$-value & 69.16 & 45.70 \\
\hline$p$-Value & $<0.0001$ & $<0.0001$ \\
\hline $\operatorname{LSD}(p=0.05)$ & $(0.87)$ & 1.09 \\
\hline
\end{tabular}

Figures in parentheses are the means of arc sine $\sqrt{ }$ percentage transformations; Means with the same letter within a column are not significantly different (LSD: $P>0.05$ ). 


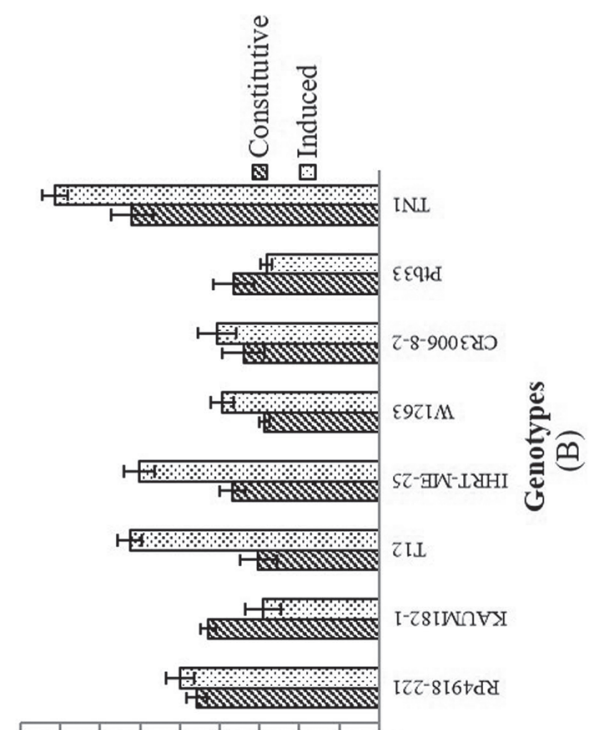

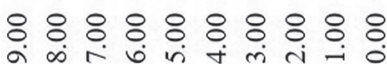

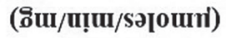

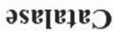
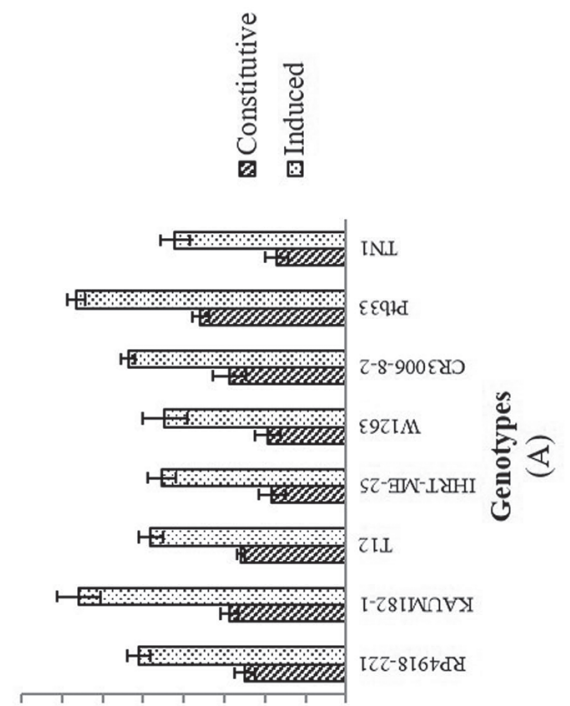

๑

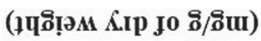

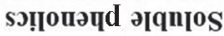

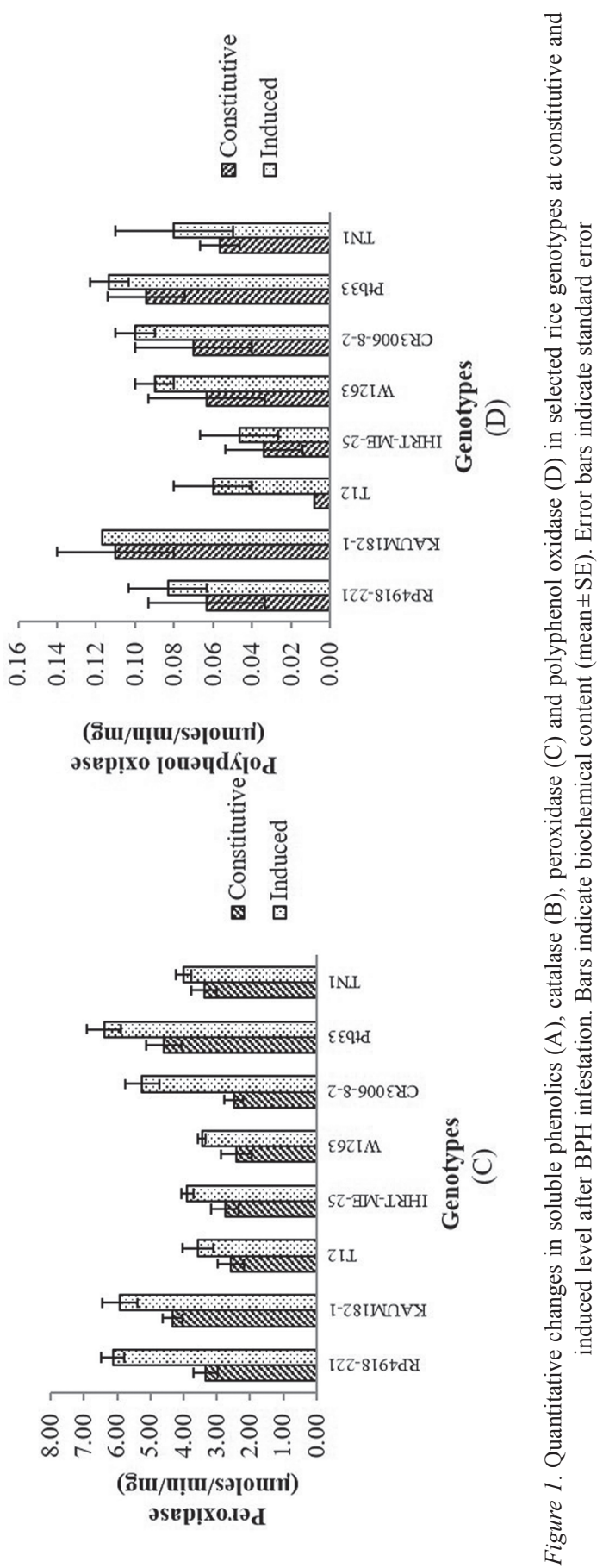

Cereal Research Communications 45, 2017 


\section{Biochemical constituent studies}

The soluble phenolic content at constitutive and induced level in plants was observed to be maximum in Ptb33 followed by KAUM182-1 and CR3006-8-2 (Table S1*; Fig. 1(A)). The activity of CAT in Ptb33 and KAUM182-1 decreased 22.53-32.91\% from initial level after BPH infestation and partially increased in RP4918-221 (9.19\%) and CR30068-2 (19.41\%) (Table S1; Fig. 1(B)). The constitutive and induced activity of PO was maximum in resistant genotypes (Table S1; Fig. 1(C)). No significant difference was observed in the activity of PPO among genotypes at constitutive and induced levels of BPH infestation (Table S1; Fig. 1(D)).

\section{Correlation studies}

A negative relationship between honeydew excretion $(-0.61,-0.50,-0.40)$, nymphal emergence $\left(-0.70^{*},-0.58,-0.36\right)$, growth index $\left(-0.81^{* *},-0.70^{*},-0.59\right)$ and nymphal survival $\left(-0.84^{* *},-0.73^{*},-0.53\right)$ was observed between soluble phenolics, peroxidase and polyphenol oxidase activity, respectively, while a positive relationship was observed with catalase (Table 4). Likewise, a reverse trend was observed between nymphal development period and biochemical constituent (Table 4).

Table 4. Correlation between antibiosis components and biochemical constituents

\begin{tabular}{|l|c|c|c|c|}
\hline \multicolumn{1}{|c|}{ Parameters } & $\begin{array}{c}\text { Soluble } \\
\text { phenolics }\end{array}$ & Catalase & Peroxidase & Polyphenol oxidase \\
\hline Honeydew excretion & -0.61 & $0.89^{* *}$ & -0.50 & -0.40 \\
\hline Nymphal development period & $0.94^{* *}$ & $-0.93^{* *}$ & $0.80^{* *}$ & $0.78^{*}$ \\
\hline Nymphal emergence & $-0.70^{*}$ & $0.85^{* *}$ & -0.58 & -0.36 \\
\hline Growth index & $-0.81^{* *}$ & $0.93^{* *}$ & $-0.70^{*}$ & -0.59 \\
\hline Nymphal survival & $-0.84^{* *}$ & $0.89^{* *}$ & $-0.73^{*}$ & -0.53 \\
\hline
\end{tabular}

*Significant at 5 per cent level of significance; **Significant at 1 per cent level of significance.

\section{Discussion}

\section{Phenotyping for antibiosis}

The seedbox screening method is widely adopted worldwide to phenotype the genotypes against BPH (Horgan et al. 2015; Sarao et al. 2016) due to its high throughput efficiency. This study mainly measures nymphal feeding response and is very subjective in terms of time of scoring the entries in relation to damage noted on the TN1. So this method has been widely adopted in reporting new sources of BPH resistance and studies on inheritance of resistance (Jena et al. 2002; Jena and Kim 2010) as well as used for map based cloning and characterization of BPH resistance genes (Wang et al. 2015; Hu et al. 2015).

\footnotetext{
*Further details about the Electronic Supplementary Material (ESM) can be found at the end of the article.
} 
Measurement of honeydew excreted by BPH is a best method for complementing the seedbox screening in several studies (He et al. 2013; Jena et al. 2015). By computing the area of honeydew excretion, the feeding of the BPH could be determined. Resistant varieties inhibit the feeding activity of BPH due to different plant metabolites which make them less preferred for feeding and this was reflected in low honeydew excretion (He et al. 2013; Jena et al. 2015). Less nymphal emergence and prolong nymphal development period was found in resistant genotypes as compared to others due to nutritionally deficient food (Maheshwari et al. 2006). The nymphal survival is the best test for studying the antibiosis component of plant resistance. Even the resistant genotypes in the current study had shown a nymphal survival to the range of 49-66\% (Seo et al. 2009; Qiu et al. 2011; He et al. 2013), which will put less selection pressure on the insect population and thus avoids the rapid adaptation of BPH. Lower growth index on resistant genotypes conveyed the adverse influence of plant nutrition on nymphal survival and development rate (Syobu et al. 2011; Kumar et al. 2012).

\section{Enzymatic and non-enzymatic antioxidants related to defense}

In our studies we observed that the changes in soluble phenolic content at induced level after BPH infestation was negatively correlated with BPH development. Similar observations were also reported by the other scientists (Vanitha et al. 2011; Dharshini and Gowda 2014). Rani and Jyotsna (2010) found that increase in the concentration of phenolic compounds is according to the extent of tissue damage caused by the feeding insects. Higher and timely activity of PO in resistant genotypes as compared to susceptible genotypes may interfere with the growth and development of BPH (Castillo 1992). PO may induce the formation of structural barriers such as thickened cell wall that inhibit feeding (Wei et al. 2009). PPPO activity decreases the nutritional quality of infested plants by converting soluble phenolic compounds into quinones that eventually prevent the digestion of proteins in insects (Alagar et al. 2007). We observed higher activity of CAT in susceptible genotypes which is an anti-oxidative enzyme and its inhibition leads to elevated levels of $\mathrm{H}_{2} \mathrm{O}_{2}$, which has a role in signalling pathways (Noctor and Foyer 1998; Grant and Loake 2000).

Rice genotypes KAUM182-1, RP4918-221 and CR3006-8-2 have displayed high level of antibiosis against BPH. These genotypes has emerged as a new sources of resistance to BPH which can be used in hybridization programme to breed durable BPH resistant rice varieties, which will ultimately form the core of IPM strategy for BPH management.

\section{References}

Alagar, M., Suresh, S. 2007. Population buildup of brown planthopper, Nilaparvata lugens on selected rice genotypes. Indian J. Plant Prot. 35:32-35.

Alagar, M., Suresh, S., Samiyappan, R., Saravanakumar, D. 2007. Reaction of resistant and susceptible rice genotypes against brown planthopper (Nilaparvata lugens). Phytoparasitica 35:346-356. 
Bastin, M., Unluer, O. 1972. Effect of actinomycin D on formation of enzymes in Jerusalem artichoke tuber slices. Planta 102:357-361.

Castillo, F.J. 1992. Peroxidase and stress. In: Penel, C., Gaspar, T., Greppin, H. (eds), Plant Peroxidases, Topics and Detailed Literature on Molecular, Biochemical and Physiological Aspects. University of Geneva. Geneva, Switzerland, pp. 187-203.

Chance, B., Maehly, A.C. 1955. Effects of saline stress and calcium on lipid composition in bean roots. Phytochem. 32:1131-1136.

Dharshini, G.M., Gowda, K.S. 2014. Biochemicals basis of resistance in rice landraces to brown planthopper, Nilaparavata lugens (Stal). Current Biotica 8:213-219.

Gomez, K.A., Gomez, A.A. 1984. Statistical Procedures for Agricultural Research. 2nd ed. Wiley-Interscience. New York, USA. pp. 1-653.

Grant, J.J., Loake, G.L. 2000 Role of reactive oxygen intermediates and cognate redox signalling in disease resistance. Plant Physiol. 124:21-29.

Gurr, G.M., Liuz, J., Read, D.M.Y., Catindig, J.L.A., Chengs, J.A., Lan, L.P. Heong, K.L. 2011. Parasitoids of Asian rice planthopper (Hemiptera: Delphacidae) pests and prospects for enhancing biological control by ecological engineering. Ann. Appl. Biol. 158:149-176.

He, J., Liu, Y., Liu, Y., Jiang, L., Wu, H., Kang, H., Liu, S., Chen, L., Liu, X., Cheng, X., Wan, J. 2013. Highresolution mapping of brown planthopper (BPH) resistance gene Bph27(t) in rice. Mol. Breed. 3:549-557.

Heinrichs, E.A., Medrano, F.G., Rapusas, H.R. 1985. Genetic Evaluation for Insect Resistance in Rice. International Rice Research Institute. Los Banos, Philippines. pp. 1-355.

Heong, K.L., Hardy, B. 2009. Planthoppers: New Threats to the Sustainability of Intensive Rice Production Systems in Asia. International Rice Research Institute. Los Baños, Philippines, pp. 1-460.

Horgan, Finbarr., Ramal, A.F., Bentur, J.S., Kumar, R., Bhanu, K.V., Sarao, P.S., Iswanto, E.H., Chien, H.V., Phyu, M.H., Bernal, C.C., Almazan, M.L.P., Alam, M.Z., Lu, Z., Huang, S.H. 2015. Virulence of brown planthopper (Nilaparvata lugens) populations from South and South East Asia against resistant rice varieties. Crop Prot. 78:222-231.

Hu, J., Xiao, C., Cheng, M., Gao, G., Zhang, Q., He, Y. 2015. Fine mapping and pyramiding of brown planthopper resistance genes $Q B p h 3$ and $Q B p h 4$ in an introgression line from wild rice $O$. officinalis. Mol. Breed. 35:3-5.

IRRI 2014. Standard Evaluation System for Rice. International Rice Research Institute. Los Baños, Philippines. pp. 1-31.

Jena, K.K., Pasalu, I.C., Rao, Y.K., Varalaxmi, Y., Krishnaiah, K., Khush, G.S., Kochert, G. 2002. Molecular tagging of a gene for resistance to brown planthopper in rice (Oryza sativa L.). Euphytica 129:81-88.

Jena, K.K., Kim, S.M. 2010. Current status of brown planthopper (BPH) resistance and genetics. Rice 3:161171.

Jena, Mayabini., Panda, R.S., Sahu, R.K., Mukherjee, A.K., Dhua, U. 2015. Evaluation of rice genotypes for rice brown plant hopper resistance through phenotypic reaction and genotypic analysis. Crop Prot. 78:119126.

Khan, Z.R., Saxena, R.C. 1985. Behavioural and physiological responses of Sogatella furcifera (Delphacidae: Hemiptera) to selected resistant and susceptible rice cultivars. J. Econ. Entomol. 78:1280-1286.

Kumar, H., Maurya, R.P., Tiwari, S.N. 2012. Study on antibiosis mechanism of resistance in rice against brown plant hopper, Nilaparvata lugens (Stal.). Ann. Plant Prot. Sci. 20:98-101.

Maheshwari, M.U., Suresh, S., Emmanuel, N. 2006. Evaluation of mechanisms of resistance in conventional and hybrid rice varieties against Nilaparvata lugens. Ann. Plant Prot. Sci. 14:319-322.

Matsumura, M., Morimura, S.S. 2010. Recent status of insecticide resistance in Asian planthoppers. Jpn. Agri. Res. Quart. 41:225-230.

Noctor, G., Foyer, C.H. 1998. Ascorbate and glutathione: Keeping active oxygen under control. Annu. Rev. Plant Physiol. Plant Mol. Biol. 49:249-279.

Qiu, Y.F., Guo, J.P., Jing, S.L., Tang, M., Zhu, L.L., He, G.C. 2011. Identification of antibiosis and tolerance in rice varieties carrying brown planthopper resistance genes. Entomol. Exp. Appl. 141:224-231.

Rani, P.U., Jyothsna, Y. 2010. Biochemical and enzymatic changes in rice plants as a mechanism of defense. Acta Physiologica P1. 32:695-701. 
Sarao, P.S. 2015. Integrated management of insect-pests of rice and basmati. Prog. Fmg. 51:9-12.

Sarao, P.S., Sahi, K.G., Neelam, K., Mangat, G.S., Patra, B.C., Singh, K. 2016. Donors for resistance to brown planthopper Nilaparvata lugens (Stål) from wild rice species. Rice Sci. 23:219-224.

Seo, B.Y., Jung, J.K., Choi, B.R., Park, H.M., Lee, B.H. 2009. Resistance-breaking ability and feeding behaviour of the brown planthopper, Nilaparvata lugens, recently collected in Korea. In: Heong, K.L., Hardy, B. (eds), Planthoppers: New Threats to the Sustainability of Intensive Rice Production Systems in Asia. International Rice Research Institute. Los Banos, Philippines. pp. 303-314.

Shannon, L.M., Kay, E., Lew, J.Y. 1966. Peroxidase isozymes from horseradish roots. I. Isolation and physical properties. J. Biol. Chem. 241:2166-2172.

Swain, T., Hills, W.E. 1959. Phenolic constituents of Prunus domestica: The qualitative analysis of phenolic constituents. J. Sci. Food. Agric. 10:63-68.

Syobu, S., Otuka, A., Matsumura, M. 2011. Trap catches of the small brown planthopper, Laodelphax striatellus (Fallen) (Hemiptera: Delphacidae), in Northern Kyushu district, Japan in relation to weather conditions. Appl. Entomol. Zool. 46:41-50.

Vanitha, K., Suresh, S., Gunathilagaraj, K., 2011. Influence of brown planthopper Nilaparvata lugens (Stal.) feeding on nutritional biochemistry of rice plant. Oryza 48:142-146.

Wang, Y., Cao, L., Zhang, Y., Cao, C., Liu, F., Huang, F., Qiu, Y., Li, R., Lou, X. 2015. Map-based cloning and characterization of $\mathrm{BPH} 29$, a $\mathrm{B} 3$ domain-containing recessive gene conferring brown planthopper resistance in rice. J. Exp. Bot. 318:3-11.

Wei, Z., Hu, W., Lin, Q., Cheng, X., Tong, M., Zhu, L., Chen, R., He, G. 2009. Understanding rice plant resistance to the brown planthopper (N. lugens): A proteomic approach. Proteomics 9:2798-2808.

\section{Electronic Supplementary Material (ESM)}

Electronic Supplementary Material (ESM) associated with this article can be found at the website of CRC at http://www.akademiai.com/content/120427/

Electronic Supplementary Table S1. Biochemical constituent of selected rice genotypes at constitutive and induced level after infestation by $N$. lugens 